\title{
A Brief Analysis on the Mission of Youth of the New Era
}

\author{
Mengke Yan* \\ Marxist College, Henan Polytechnic University, Jiaozuo 454003, Henan Province, China \\ *Corresponding author: Mengke Yan, 18438608807@163.com
}

\begin{abstract}
Socialism with Chinese characteristics has entered a new era, marking the beginning of a new era of youth. In contemporary China, the new era has given young people the historical mission of seeking happiness for the Chinese people, the rejuvenation of the Chinese nation, and for the progress of the people in the world. Cultivating the mission and responsibility of youth is not only the requirement for national development, but also for young people to be qualified in the new era. Therefore, youth of the new era should clarify their status and mission, cultivate responsibility, and strive to become builders and successors of socialist modernization.
\end{abstract}

Keywords: Youth; New age; Youth mission

Publication date: October 2021; Online publication: October 29, 2021

\section{Introduction}

Socialism with Chinese characteristics has entered a new era, and the Chinese nation has ushered in a great leap, becoming more confident and capable than at any historical point of time, to achieve the great rejuvenation goal of the Chinese nation. In such a new era, which has been carried forward and carried on, young people have been given a new mission. Therefore, the youth of the new era bear the historical mission of seeking happiness for the Chinese people, the rejuvenation of the Chinese nation, and for the progress of the people in the world. Youth of the new era, as builders and successors of the modern socialist power, can only firmly believe, work hard, innovate, strive to be "China's good sons and daughters" as well as "ideal, competent, and responsible" in realizing the great rejuvenation of the Chinese dream of the Chinese nation in the social value of blooming glory.

\section{Social responsibility highlights the status of youth}

"The hope of the country is the youth, the future of the nation is the youth," "The responsibility of the times belongs to the youth, the glory of the times belongs to the youth," and so on illustrate the close connection between youth and the future of the country. They reflect that the development of the country cannot be detached from the young people, thus emphasizing the historical status of youth.

\subsection{The impetus for historical progress}

"Youth is the most sensitive barometer of the era," stated General Secretary Xi Jinping. This is a profound understanding of the relationship between youth and the times. Throughout history, youth have played an important role in any great change. In the three large-scale revolutionary movements that broke out in France, Germany, and Britain in the 1830s and 1940s, young people were active participants and the promoters of these movements. In his analysis of the German Revolution, Engels stressed, "It will be the 
young people of Germany who will bring about this change ${ }^{[1]}$." In modern China, the reform law, the Revolution of Xinhai, the May Fourth Movement, and other patriotic movements that saved the lives of many people were positive response as seen in their enforcement of these movements. Young people are willing to accept new ideas, and by virtue of their advanced ideas, they have made suggestions for the construction of the Party and the country, becoming ideological leaders of different eras, thus promoting the progress and development of the society.

\subsection{The force of life for the development of the Party and the country}

General Secretary Xi Jinping said, "Representing the vast number of young people, winning the vast number of young people, and relying on the vast number of young people are the Party's continuous progress from victory to victory with an important guarantee ${ }^{[2]}$." Therefore, youth is the future hope of the Party ${ }^{[2]}$. First, young people are energetic, able to adapt to the development of the times, as well as have strong learning and scientific research abilities. Therefore, they are able to play a major role in driving socialist modernization. Second, by virtue of their theoretical knowledge and professional skills, young people have become the main body of all walks of life in China. Contributing wisdom to China's economic development, they bear the heavy responsibility of building the motherland. Now, the development of information technology is inevitable; thus, the development of the country must rely on science and technology. Today's China needs to build a world scientific and technological power more than at any time in history. Third, youth are a generation that moves forward together with the new era. In the era of realizing the goal of "two hundred years" and the great rejuvenation of the Chinese dream of the Chinese nation, the golden period of personal development is unified with the golden period of national development. Only by moving in the same direction as the development of the country and the nation, the development of youth can achieve the goal of "two hundred years" and the great rejuvenation of the Chinese dream while realizing personal value.

\subsection{The promoter of world peace and development}

General Secretary Xi Jinping stressed, "Youth have ideals and responsibilities and mankind has hope; the noble cause of promoting peace and development of mankind has a steady stream of powerful forces [3]." Youth have important significance for the cause of world peace, and they are the main body that shapes the world and the future. First, contemporary youth live in the information age, where their ideas and thinking are more open. They are more inclusive of values, and they easily understand as well as absorb cultures from various countries. Therefore, it is of a unique advantage to promote international exchanges and world development among youth of the new era. Second, China has always been committed to safeguarding world peace and development. In recent years, China has advocated the establishment of a new type of international relationship with the win-win cooperation as its core and has put forward the concept of building a community of human destiny, thus providing a great opportunity and a broad stage for the youth to participate in international affairs and devote themselves to the cause of world peace and development. The young people would eventually play a leading role in promoting national communication and exchanges, world peace and development, as well as advancing world civilization.

\section{The new era has given young people a new mission}

\subsection{Young people bear the responsibility of seeking happiness for the Chinese people}

The report of the 19th National Congress of the Communist Party of China clearly stated that the main contradiction in the country is between the growing needs of the people and the uneven and inadequate development. Seeking happiness for the people refers to solving the problem of imbalance and inadequate 
development. Realizing the goal of "two hundred years" is the theme of the times in China today, and it is also a priority for young people to seek happiness for the Chinese people. At present, China is achieving its first goal, which is to build a well-off society in an all-rounded way. This requires young people to actively participate in a constructive manner. Youth should inject vitality into China's economic development, lead the social style, and devote themselves to the harmonious development of the society. At the same time, they should face up to challenges and difficulties as well as resolve obstacles. The realization of building a well-off society in an all-rounded way would open up opportunities in the direction of the second goal; namely, the new journey of building a modern socialist country in an all-rounded way. This further requires young people to bear the responsibility and strive as in all walks of life blooming light.

\subsection{Young people shoulder the mission of realizing the Chinese dream: the great rejuvenation of the Chinese nation}

The Chinese dream is the dream of every Chinese, and this great dream can only be realized if Chinese people unite and work toward a common goal. As an important force in social construction and realizing the Chinese dream, young people should shoulder this mission. As General Secretary Xi Jinping pointed out, "The Chinese dream is ours, but also yours, the younger generation. The great rejuvenation of the Chinese nation will eventually become a reality in the relay of the vast number of young people ${ }^{[4]}$." At present, China is approaching the great rejuvenation of the Chinese nation than at any time in history, and this is when the nation needs the young people to serve the motherland and actively participate in the process of realizing the Chinese dream. They should always regard the realization of the great rejuvenation of the Chinese nation as their goal. As the older generation have built a solid foundation for the youth of the new era, the young people now stand on the shoulders of their predecessors. As long as there is unremitting effort, the great goal of national rejuvenation would certainly be achieved. Being the glory that has been passed down to the young people and also the way for young people to realize their personal values, there is no reason why young people should not strive toward this goal. As a member of the Chinese nation, the youth, no matter where they are or what the situation is, should set up the goal of "fighting for the great rejuvenation of the Chinese nation" and strive to become people of the new era, who can take on the great responsibility of the national rejuvenation.

\subsection{Young people have a mission to make progress for the people in the world}

UNESCO has stated, "Youth shaping the world." Youth in the new era is an important force to promote the development of the world and the progress of mankind. Looking back on the course of social development, it can be appreciated that the human society has experienced four revolutions and realized changes from manual labor to mechanization, electrification, automation, and finally, intelligence, which is evident of the world's progress. This process cannot be separated from the youth's active participation. The fourth scientific and technological revolution is based on the development of new energy and biotechnology as the core and focus; that is, the development of intelligence. In this new century, the new era of youth have received the latest science and technology education; hence, it is possible for them to accept and develop into an intelligent generation. The effective development of intelligence can effectively alleviate the human survival crisis and current environmental issues, such as the greenhouse effect and ecological deterioration. In this manner, human progress can then be promoted. There is therefore no reason why young people should not work toward this goal. This is the mission given to young people by the times, but it is also a stage for young people to achieve a vibrant life. Any young person, regardless of race, sex, status, etc., as a member of the human race that belongs to the world, should struggle for the progress of the people in the world and become a part of the new-age youth who has contributed to the world. 


\section{The mission of the new era of youth to assume the implementation}

"Young people are not only dream chasers, but also dreamers. Chasing dreams requires passion and ideals, but dreaming requires struggle and dedication. Young people should release the passion of youth in the struggle and pursuit of youth ideals, paving the way for national rejuvenation and the building of the motherland ${ }^{[5]}$." This is General Secretary Xi Jinping's interpretation of the new era of youth and also the new requirements for the new era.

\subsection{Having firm belief and lofty ideals as the core requirements of the mission}

The report of the 19th National Congress of the Communist Party of China clearly stated, "The vast number of young people should firmly believe in ideals, have high ambitions, be down-to-earth, and bravely face the tide of the times ${ }^{[4]}$." General Secretary Xi Jinping's choice of words, such as "calcium" to complement the spirit, "master switch" to work out ideas, and "first button" to hold up life, is enough to prove its importance. First, young people of the new era should learn about Marxism and firmly believe in the doctrine. At the same time, they should consciously arm their minds with Xi Jinping's Thought on Socialism with Chinese Characteristics for the New Era and participate in the reform and opening-up as well as in the socialist modernization. Second, the youth of the new era should strengthen themselves in the "four matters of confidence," take the common ideal of socialism with Chinese characteristics and the lofty ideal of communism as guiding directions, inherit and carry forward the national spirit with patriotism as the core, firmly believe in the concept of socialism with Chinese characteristics, promote the great rejuvenation of the Chinese dream of the Chinese nation, integrate personal ideals into the cause of the country and the nation, as well as strive to transform into flexible talents of the motherland. Third, young people should strengthen their ability to distinguish right from wrong, make correct judgments rather than having wrong thoughts, such as historical nihilism and extreme individualism, as well as maintain a clear mind and firm political stance at all times. Young people should have faith in order to continue to assume the mission of the new era.

\subsection{Realistic and pragmatic practice on skills as the essence in the brave mission of youth of the new era}

On May 2, 2018, General Secretary Xi Jinping raised four aspirations for the young people of the new era at a symposium of teachers and students at Peking University, which include being patriotic, inspirational, truth-seeking, and hardworking. Among them, "truth-seeking" refers to exploring the truth and holding on to the law, while "hardworking" refers to learning diligently, based on the truth. The characteristics of the new era provide new requirements for the development of young people. One of the requirements is to be sensitive to knowledge. Engels mentioned that the task of young people, especially the Communist Youth League and other organizations, can be expressed in one sentence: "It is to learn" ${ }^{[6]}$. Young people should make effort to learn scientific and cultural knowledge, pay attention to internalize what they have learned, form their own opinions, and improve their self-cultivation to meet the development needs of the society. Young people should concentrate on classics and draw wisdom from them to build a solid theoretical foundation. The second is to pay attention to the cultivation of practical skills. The modern society, especially in socialist modernization, needs not only knowledge-based talents, but also skilled personnel. Therefore, based on their responsibilities, young people should learn to solve practical problems in order to build on their knowledge and skills. It would also be beneficial to fully mobilize their enthusiasm so that in the process of joining the construction of the motherland and dedication to the society, young people would be able to achieve personal values. 


\subsection{Aggressive innovation and stimulating creative vitality as important conditions for young people to take on the mission}

Young people are the most creative and active group in the society. In face of the development of the Party and the country's life force, young people should be in the forefront of innovation and creation. General Secretary Xi Jinping directly pinpointed at the young people, "Dare to be a pioneer, not a guest or a visitor so that innovation becomes the impetus for the voyage of youth and entrepreneurship becomes the energy in the fight of youth in order for the youth in the country to glow brilliantly ${ }^{[7]}$." As the backbone of national development and socialist modernization, young people should make new achievements in the new era. First, young people should learn new knowledge in a timely manner and speed up the pace of knowledge renewal, so that there would be progress from time to time according to situations ${ }^{[8]}$, the knowledge learned would be used in the vivid practice of socialism with Chinese characteristics, and their ability and level of work would be continuously improved. Second, the concept of innovation as the driving force should be adhered to, with a global vision and sense of innovation, while stimulating creative vitality and invigorating the concept of bravely walk in the forefront of the times as pioneers ${ }^{[9]}$. Young people should actively participate in the reform and opening-up with a broad vision, become innovative talents, as well as contribute to the realization of the well-being of the Chinese people, the rejuvenation of the Chinese nation, and the progress of the people in the world.

\section{Conclusion}

The new historical orientation compels young people to take up the baton of national prosperity, national rejuvenation, people's happiness, and world peace. Therefore, the vast number of young people should firmly believe, be high-minded, and bravely face the tide of the times even during struggles, in order to achieve people's happiness, national rejuvenation, world progress, and the great goal of struggle.

\section{Disclosure statement}

The author declares that there is no conflict of interest.

\section{References}

[1] 1980, Marx and Engels Lenin Stalin on Youth, China Youth Press, 3.

[2] Xi J, 2018, Xi Jinping's Collective Talks with the Members of the New Leadership Team of the Central Committee of the League Emphasize that on Behalf of the Vast Number of Young People to Win the Vast Number of Young People Rely on the Vast Number of Young People to Dare to Dream and Dare to Pursue Dreams and Work Hard in the Dream. People's Daily, (01).

[3] 2017, Excerpts from Xi Jinping's Discussion on the Work of Youth and the Communist Youth League, Central Literature Press, Beijing, 7.

[4] Xi J, 2017, Winning to Build a Well-off Society in an All-round Way to Win the Great Victory of Socialism with Chinese Characteristics in the New Era - Report at the 19th National Congress of the Communist Party of China. People's Daily, (01).

[5] Xi J, 2018, General Secretary Xi Jinping's Speech at the Symposium of Teachers and Students at Peking University. Xinhua News Agency, (01).

[6] 1986, Lenin's Full Collection (Vol. 39), People's Press, Beijing, 293.

[7] Central Documentation Research Office of the Communist Party of China, 2017, Excerpts from Xi Jinping's Discussion on the Work of Youth and the Communist Youth League, 54. 
[8] 2016, Xi Jinping Stressed at the National Conference on Ideological and Political Work in Colleges and Universities: "To Run Ideological and Political Work through the Whole Process of Education and Teaching and to Create a New Situation in the Development of Higher Education in China". The People's Daily, (01).

[9] Xi J, 2014, Young People Should Consciously Practice the Core Values of Socialism - Speech at the Symposium of Teachers and Students of Peking University, People's Press, Beijing. 